\title{
Publisher Correction: PTEN regulates glioblastoma oncogenesis through chromatin-associated complexes of DAXX and histone H3.3
}

Jorge A. Benitez, Jianhui Ma, Matteo D'Antonio, Antonia Boyer, Maria Fernanda Camargo, Ciro Zanca, Stephen Kelly, Alireza Khodadadi-Jamayran, Nathan M. Jameson, Michael Andersen, Hrvoje Miletic, Shahram Saberi, Kelly A. Frazer, Webster K. Cavenee \& Frank B. Furnari

Nature Communications 8:15223 doi: 10.1038/ncomms15223 (2017); Published 12 May 2017; Updated 25 May 2018

The originally published version of this Article contained an error in Fig. 1. In panel d, the uppermost western blot was inadvertently inverted during typesetting of the figure. This has now been corrected in both the PDF and HTML versions of the Article.

\footnotetext{
(c) (i) This work is licensed under a Creative Commons Attribution 4.0 International License. The images or other third party material in this article are included in the article's Creative Commons license, unless indicated otherwise in the credit line; if the material is not included under the Creative Commons license, users will need to obtain permission from the license holder to reproduce the material. To view a copy of this license, visit http://creativecommons.org/licenses/by/4.0/

(C) The Author(s) 2018
} 